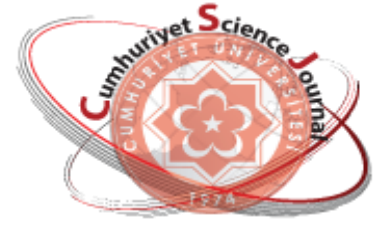

e-ISSN: $2587-246 X$

ISSN: 2587-2680

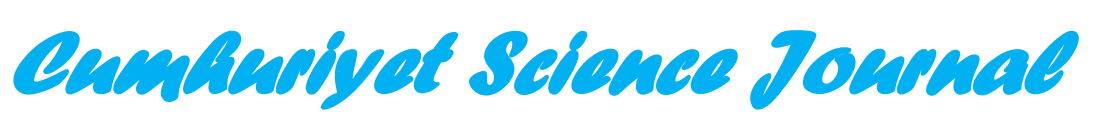

CST

Cumhuriyet Sci. J., Vol.39-3(2018) 734-744

\title{
DFT Study on Antioxidant Action Mechanisms of Naphthoquinone-Urazole Hybrids
}

\author{
Dilara ÖZBAKIR IŞIN \\ Cumhuriyet University, Faculty of Science, Department of Chemistry, Sivas, TURKEY \\ Received: 17.08.2018; Accepted: 25.09.2018 \\ http://dx.doi.org/10.17776/csj.454294
}

\begin{abstract}
The aim of this study is on the evaluation of the antioxidant activities of the investigated naphthoquinone-urazole hybrids by comparing our theoretical results with experimental results and on the elucidation the antioxidant action mechanisms. For this purpose, quantum chemical calculations were performed at the B3LYP/6-311++G(d,p) level for the investigated naphthoquinone-urazole hybrids and their ionic forms in the gas phase and in water. The solvation effect of water on the antioxidant activity was examined using the conductor-like polarizable continuum model (C-PCM) at the same level of theory. The antioxidant action mechanisms for the investigated naphthoquinone-urazole hybrids were assessed thermodynamically by several physicochemical parameters.
\end{abstract}

Keywords: Antioxidant mechanism, naphthoquinone-urazole hybrids, DFT, HAT, SET-PT, SPLET.

\section{Naftokinon-Urazol Melezlerinin Antioksidan Etki Mekanizmaları Üzerine DFT Çalışması}

Özet. Bu çalışmanın amacı, naftokinon-urazol melezlerinin antioksidan aktivitelerinin teorik ve deneysel sonuçlar karşılaştırarak değerlendirilmesi ve antioksidan etki mekanizmalarının araştırılmasıdır. Bu amaçla, incelenen naftokinon-urazol melezleri ve iyonik formları için kuantum kimyasal hesaplamalar B3LYP / 6-311 $++\mathrm{G}(\mathrm{d}, \mathrm{p})$ düzeyinde hem gaz hem de su fazında yapılmıştır. Antioksidan aktiviteleri üzerine suyun çözücü etkisi, aynı hesaplama düzeyinde C-PCM yöntemi kullanılarak araştırıldı. Naftokinon-urazol melezleri için antioksidan etki mekanizmaları, bazı fizikokimyasal parametreler kullanılarak termodinamik olarak değerlendirildi.

Anahtar Kelimeler: Antioksidan mekanizma, naftokinon-urazol melezleri, DFT, HAT, SET-PT, SPLET.

\section{INTRODUCTION}

The reactive oxygen species formed during biochemical reactions in the body are radicals with high reactivity. Because these reactive free radicals can attack to proteins in tissues, lipids in cell membranes, carbohydrates, amino acids and DNA, they are responsible for many health problems, such as cancer, cardiovascular disorders, atherosclerosis, asthma, arthritis, diabetes neurodegenerative disorders: Alzheimer`s, Parkinson`s diseases and dementia
[1]. Anti-oxidant compounds either natural or synthetic can protect biomolecules against undesired oxidative damage caused by the free radicals and repair the damages caused by free radicals. [2].

Naturally occurring quinones such as dactinomycin, anthracycline antibiotics and mitomycin-C have been clinically used for cancer chemotherapy [3,4]. New natural and synthetic cytotoxic compounds of this group have the para-quinone moiety in the structure of 
most of them and they have antioxidant properties [5, 6]. On the other hand, urazole moiety exhibits a myriad of biological functions such as anticonvulsant, antifungal, herbicidal, hypolipidemic and insecticidal activities [7-10]. Because of the thought that it can create synergistic effects with hybridization of different bioactive molecules, a novel series of naphthoquinone-urazole hybrids were synthesized and investigated experimentally for antioxidant (DPPH radical scavenging activity) and anticancer activity. Their findings suggested that the investigated naphthoquinone-urazole hybrids exhibited high anti-oxidant activity [11]. Theoretically investigating the antioxidant action mechanisms of these synthesized hybrids can be of interest. Here, our focus is on the evaluation of the antioxidant activities of the investigated naphthoquinone-urazole hybrids by comparing our theoretical results with experimental results and on the elucidation the antioxidant action mechanisms. These calculations may illustrate the SAR and radical scavenging mechanism of naphthoquinone-urazole hybrids, which may help expand their applications in pharmaceutical science.

The antioxidant activity can be assessed thermodynamically by several physicochemical parameters such as bond dissociation enthalpy (BDE), proton dissociation enthalpy (PDE), proton affinity (PA), ionization potential (IP) and electron transfer enthalpy (ETE). In this study, the structural and electronic properties of the selected naphthoquinone-urazole hybrids and their radicals were investigated at DFT level. The solvation effects on the antioxidant activity were taken into account by using the conductor-like polarizable continuum model (C-PCM) with different dielectric constant $\left(\varepsilon=78.39, \mathrm{H}_{2} \mathrm{O}\right)$. The three antioxidant action mechanisms, hydrogen atom transfer (HAT), single electron transfer-proton transfer (SET-PT) and sequential proton loss electron transfer (SPLET) were elucidated. The reaction enthalpies related to the steps in these mechanisms were computed in gas phase and in water. In addition, spin densities in free radicals were also calculated.

\section{METHOD}

The three basis antioxidant mechanisms are proposed in the literature $[12,13]$.

The first of these is hydrogen atom transfer mechanism (HAT).

$\mathrm{R}^{\bullet}+\mathrm{AH} \rightarrow \mathrm{RH}+\mathrm{A}^{\bullet}$

In this mechanism, the free radical $\left(\mathrm{R}^{*}\right)$ removes a hydrogen atom from the antioxidant (AH), and a radical form of antioxidant appears. The reactivity of a compound can be predicted by calculating the A-H bond dissociation enthalpy (BDE), where the lower the BDE value the higher the expected activity.

The second one is single electron transfer-proton transfer (SET-PT) mechanism. This mechanism is a two-step reaction, where electron abstraction from $\mathrm{AH}$ is followed by proton transfer.

$\mathrm{R}^{\bullet}+\mathrm{AH} \rightarrow \mathrm{R}^{-}+\mathrm{AH}^{+\bullet}$

$\mathrm{AH}^{+\bullet} \rightarrow \mathrm{H}^{+}+\mathrm{A}^{\bullet}$

A numerical parameter related with this mechanism is ionization potential (IP) for the first step and proton dissociation enthalpy (PDE) from the $\mathrm{AH}^{+}$cation radical for the second step. Molecules with low IP and PDE values are expected to have high activity.

The other mechanism consisting of a two-stage reaction is the SPLET (Sequential proton loss electron transfer) mechanism.

$$
\begin{aligned}
& A H \rightarrow A^{-}+H^{+} \\
& A^{-}+H^{+}+R^{\cdot} \rightarrow A^{\cdot}+R H
\end{aligned}
$$

The reaction enthalpy of the first step in this mechanism corresponds to the proton affinity (PA) of the anion. The reaction enthalpy of the second step, abstraction of electron, is indicated as electron transfer enthalpy (ETE). In the present study BDE, IP and PA values were used as the main molecular descriptors in an effort to elucidate the radical scavenging activity of 
investigated compounds. From the calculated total enthalpies at $298.15 \mathrm{~K}$, these molecular descriptors were calculated using the following equation:

$$
\begin{aligned}
& \mathrm{BDE}=\mathrm{H}\left(\mathrm{A}^{\bullet}\right)+\mathrm{H}\left(\mathrm{H}^{\bullet}\right)-\mathrm{H}(\mathrm{AH}) \\
& \mathrm{IP}=\mathrm{H}\left(\mathrm{AH}^{+\bullet}\right)+\mathrm{H}\left(\mathrm{e}^{-}\right)-\mathrm{H}(\mathrm{AH}) \\
& \mathrm{PDE}=\mathrm{H}\left(\mathrm{A}^{\bullet}\right)+\mathrm{H}\left(\mathrm{H}^{+}\right)-\mathrm{H}\left(\mathrm{AH}^{+\bullet}\right) \\
& \mathrm{PA}=\mathrm{H}\left(\mathrm{A}^{-}\right)+\mathrm{H}\left(\mathrm{H}^{+}\right)-\mathrm{H}(\mathrm{AH}) \\
& \mathrm{ETE}=\mathrm{H}\left(\mathrm{A}^{\bullet}\right)+\mathrm{H}\left(\mathrm{e}^{-}\right)-\mathrm{H}\left(\mathrm{A}^{-}\right)
\end{aligned}
$$

The molecular enthalpy at $298 \mathrm{~K}(\mathrm{H})$ consisted of B3LYP/6-311++G(d,p) calculated energy values and thermal contributions to enthalpy (TCE, in which the vibrational contributions include zeropoint vibrational energy). To calculate the reaction enthalpies, the enthalpies of hydrogen atom, proton, and electron in the gas phase and solvents are required. The gas phase enthalpies of hydrogen atom, proton, and electron were $0.49765, \quad 0.00236$ and 0.00118 hartree, respectively $[13,14]$. Proton and electron solvation enthalpies were taken from reference [15], and hydrogen atom solvation enthalpies from references $[16,17]$.

All computations were performed using the Gaussian 09 AML64L-Revision-C.01 package [18]. The B3LYP functional was used for geometry optimization of each compound, radical or ionic structure by applying the $6-311++\mathrm{G}(\mathrm{d}, \mathrm{p})$ basis set [19]. The geometry optimization of anions was performed with the restricted rB3LYP/6-311++G(d,p) method. To optimize the radicals and cation radicals, the unrestricted uB3LYP/6-311++G(d,p) level of theory was carried out, because of that it gives the best results for open-shell molecular systems. For all of the optimized structures, the vibrational frequencies were calculated at same level in order to characterize the local minimum on the potential energy surfaces. In addition, the spin density for each atom of the radicals was computed using the same level of theory. Since water is the major component of all living cells, the solvation effect of water on the antioxidant activity was taken into account by using the conductor-like polarizable continuum model (C-PCM) [20] at the same level of theory.

a)

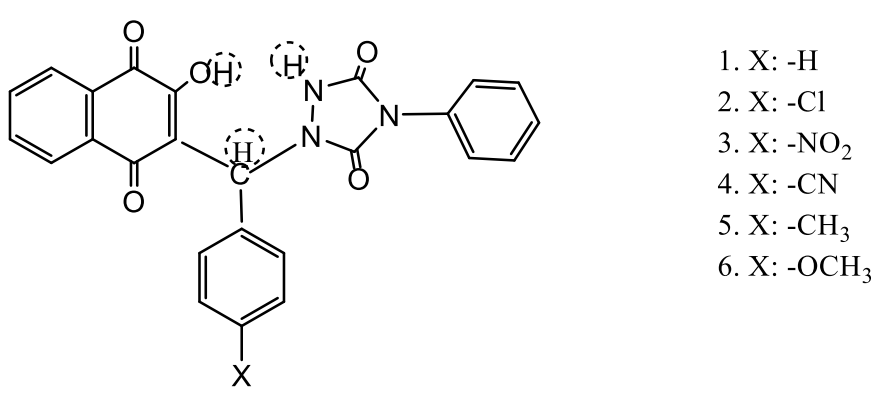

b)<smiles>Cc1cc(C(C)(C)C)c(O)c(C(C)(C)C)c1</smiles>

BHT<smiles>O=C1C=C(O)C(=O)c2ccccc21</smiles>

2-HNQ<smiles>O=c1[nH][nH]c(=O)n1-c1ccccc1</smiles>

4-PU

Figure 1. Molecular structures of a) the studied naphthoquinone-urazole hybrids and b) reference compound, butylated hydroxyl toluene (BHT) was used as a reference. 


\section{RESULTS AND DICUSSION}

The density functional theory (DFT) method have been successfully used to calculated physiochemical descriptors of polyphenolic compounds and to investigate the structureactivity relationship (SAR) for phenolic antioxidants [21-23]. The investigated naphthoquinone-urazole hybrids (Fig.1) and their corresponding radical and ionic species, the most stable conformers were optimized without symmetry restrictions by the B3LYP/6-311++G $(d, p)$ level in the gas phase and in water.
As can be seen in Figure 1, in the select hybrid structures there are three positions (It is enclosed in the circle) where hydrogen can be removed. All possible radicals and ions were evaluated, and the physiochemical descriptors calculated in the gas phase and in water for each site were given in table 1 and table2, respectively. It was also presented the natural bond orbital (NBO) distribution for the radicals formed after $\mathrm{H}$ removal on each site in Figure 2.

Table 1. B3LYP/6-311++G(d,p) BDE, IP, PDE, PA and ETE values of the studied naphthoquinone-urazole hybrids and reference compounds in gas phase. (All values are in kcal energy unit).

\begin{tabular}{|c|c|c|c|c|c|c|}
\hline \multicolumn{2}{|c|}{ Compounds } & BDE & IP & PDE & PA & ETE \\
\hline \multirow{3}{*}{1} & $\mathrm{O}-\mathrm{H}$ & 91.74 & \multirow{3}{*}{174.92} & 231.33 & 307.74 & 98.52 \\
\hline & $\mathrm{N}-\mathrm{H}$ & 77.48 & & 217.06 & 326.83 & 65.15 \\
\hline & C-H & 75.43 & & 215.01 & 328.89 & 61.04 \\
\hline \multirow{3}{*}{2} & $\mathrm{O}-\mathrm{H}$ & 91.69 & \multirow{3}{*}{176.60} & 229.59 & 307.25 & 98.94 \\
\hline & $\mathrm{N}-\mathrm{H}$ & 77.44 & & 215.34 & 324.31 & 67.63 \\
\hline & C-H & 75.18 & & 213.09 & 325.74 & 63.95 \\
\hline \multirow{3}{*}{3} & $\mathrm{O}-\mathrm{H}$ & 90.61 & \multirow{3}{*}{182.51} & 222.59 & 303.16 & 101.95 \\
\hline & $\mathrm{N}-\mathrm{H}$ & 77.77 & & 209.75 & 320.32 & 71.95 \\
\hline & C-H & 75.80 & & 207.79 & 316.27 & 74.04 \\
\hline \multirow{3}{*}{4} & $\mathrm{O}-\mathrm{H}$ & 92.48 & \multirow{3}{*}{181.24} & 225.74 & 303.98 & 103.00 \\
\hline & $\mathrm{N}-\mathrm{H}$ & 77.67 & & 210.93 & 321.10 & 71.075 \\
\hline & $\mathrm{C}-\mathrm{H}$ & 75.71 & & 208.97 & 319.64 & 70.57 \\
\hline \multirow{3}{*}{5} & $\mathrm{O}-\mathrm{H}$ & 91.25 & \multirow{3}{*}{173.04} & 232.72 & 308.22 & 97.53 \\
\hline & $\mathrm{N}-\mathrm{H}$ & 77.40 & & 218.86 & 327.47 & 64.43 \\
\hline & C-H & 74.11 & & 215.58 & 329.59 & 59.02 \\
\hline \multirow{3}{*}{6} & $\mathrm{O}-\mathrm{H}$ & 89.85 & \multirow{3}{*}{172.00} & 232.34 & 307.91 & 96.44 \\
\hline & $\mathrm{N}-\mathrm{H}$ & 77.08 & & 219.58 & 327.44 & 64.14 \\
\hline & C-H & 73.27 & & 215.77 & 329.61 & 58.17 \\
\hline \multicolumn{2}{|c|}{ BHT } & 74.46 & 169.58 & 219.38 & 338.36 & 50.60 \\
\hline \multicolumn{2}{|c|}{ 2-HNQ } & 94.34 & 208.62 & 198.74 & 327.14 & 81.70 \\
\hline \multicolumn{2}{|c|}{ 4-PU } & 79.56 & 201,21 & 192.85 & 331.32 & 62.74 \\
\hline
\end{tabular}



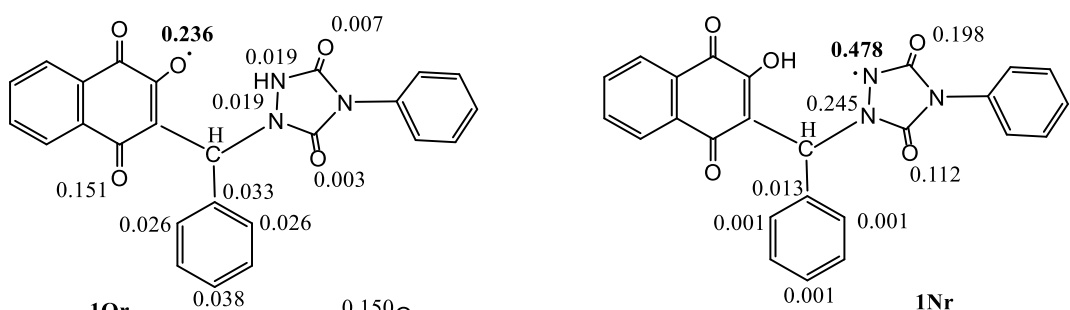

$10 \mathrm{r}$
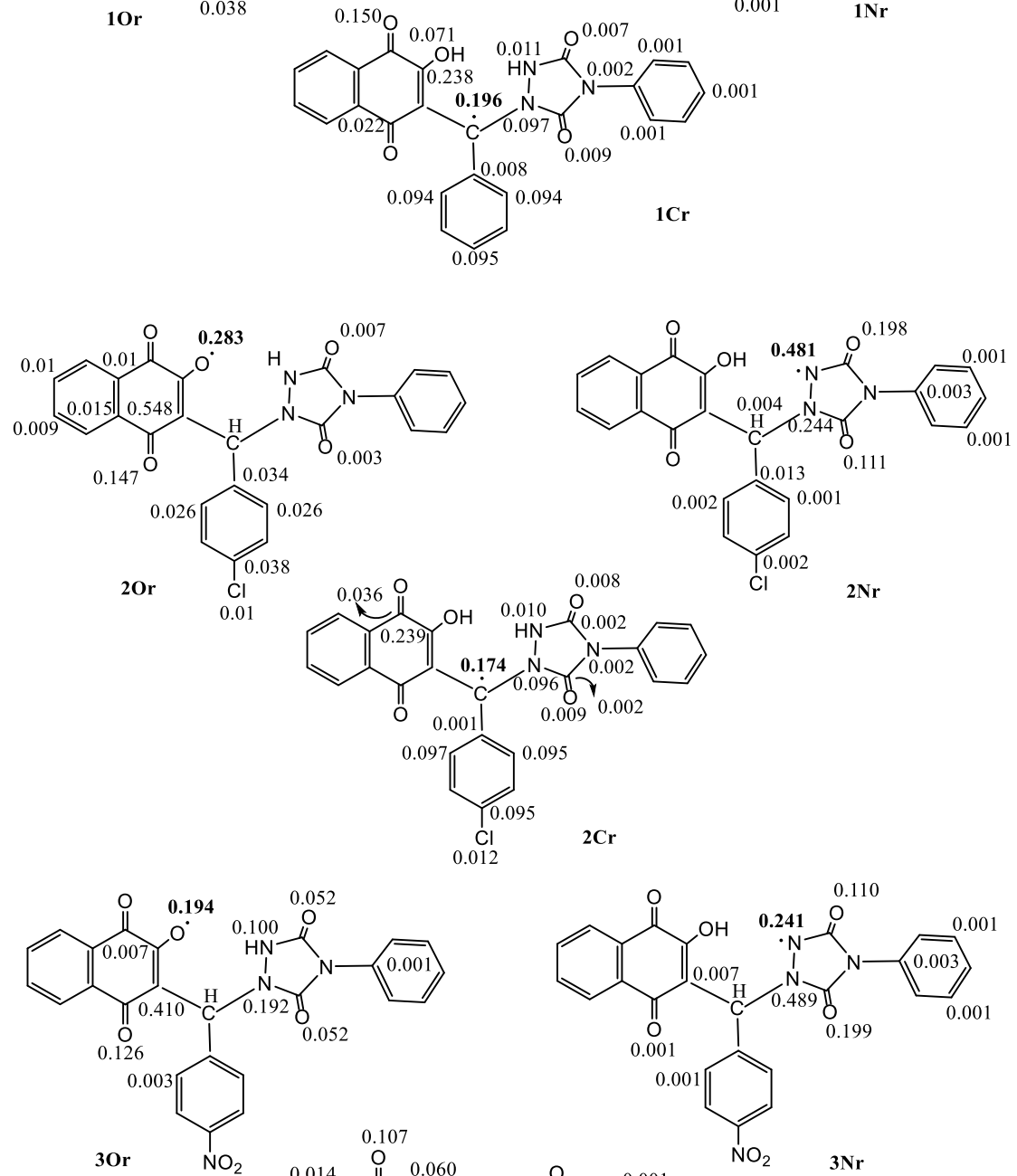

30r

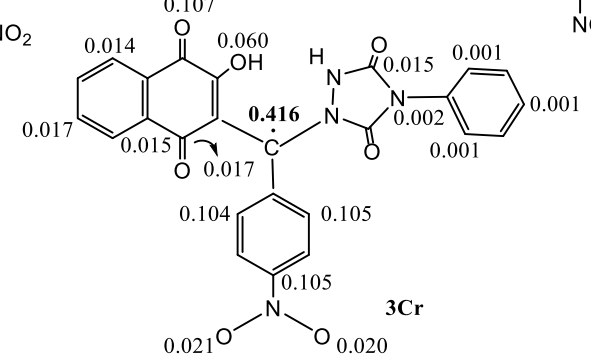



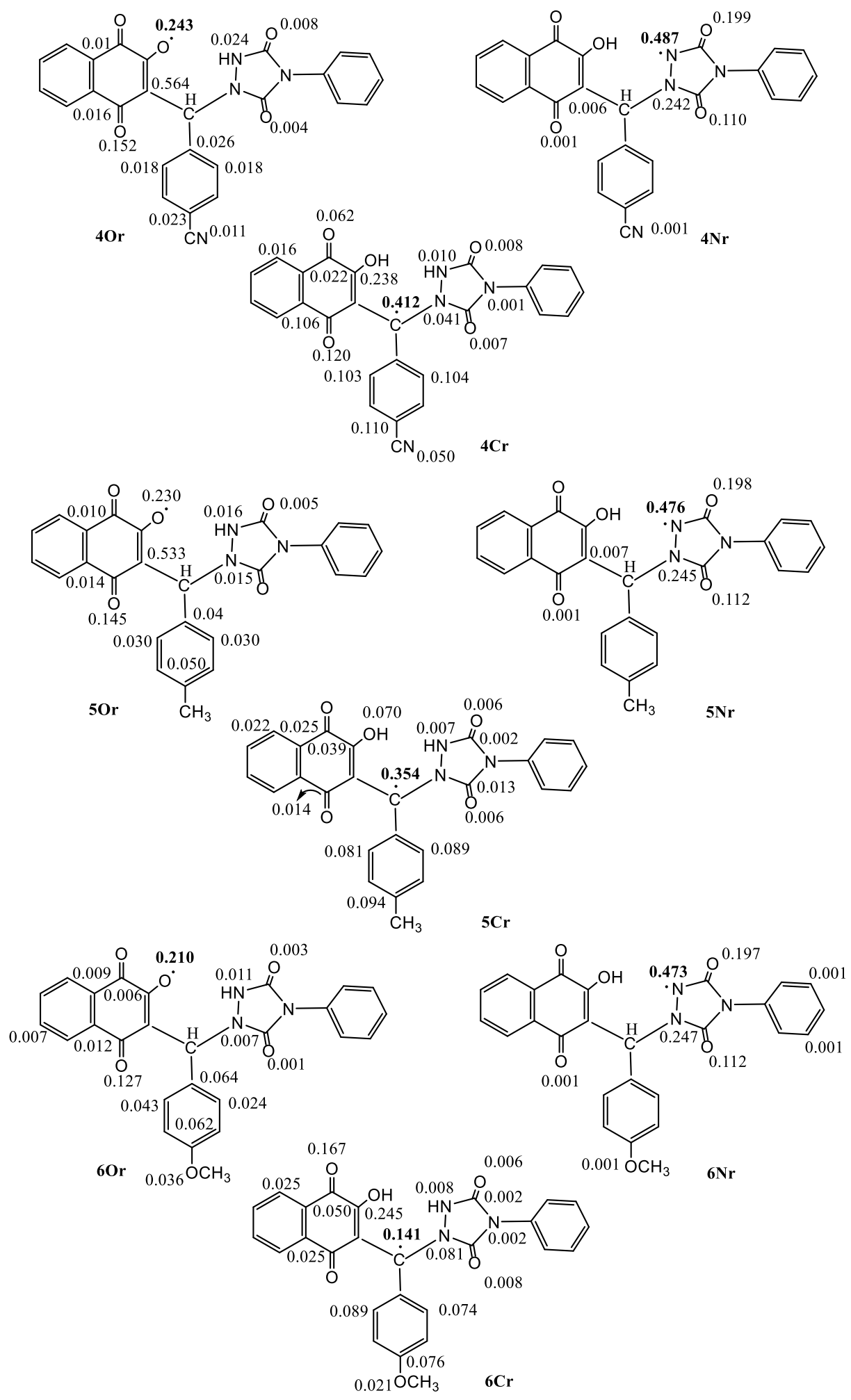

Figure 2. Spin density distribution of the radicals formed from the studied naphthoquinone-urazole hybrids computed at the B3LYP/6-311++G(p,d) level of theory in the gas phase. (Values less than 0.001 was not taken into account). 
In this study, BDEs for $\mathrm{O}-\mathrm{H}, \mathrm{N}-\mathrm{H}$ and $\mathrm{C}-\mathrm{H}$ bonds give important information related with the HAT mechanism, because a low BDE value means the faster reaction rate and high antioxidant activity. When the calculated BDE values in the gas phase and in water are examined, it is seen that the $\mathrm{C}-\mathrm{H}$ bonds have the lowest BDE values in all the studied compounds. The BDEs for 1-6 decline in order $\mathrm{O}-\mathrm{H}>\mathrm{N}-\mathrm{H}>\mathrm{C}-\mathrm{H}$ in the gas phase. The same sequence was obtained for BDEs in water. The BDE values of $\mathrm{O}-\mathrm{H}$ and $\mathrm{N}-\mathrm{H}$ bonds in all compounds are lower than those of 2-HNQ and 4PU. This result indicates that the hybridization increases the antioxidant capacity. In addition, comparing the BDEs of BHT and $\mathrm{C}-\mathrm{H}$ bonds in 16 compounds, it is seen that BDEs in 5 and 6 compounds are especially lower than that of BHT. The largest deviation between the BDEs in others (1-4) and BHT is only $1.34 \mathrm{kcal} / \mathrm{mol}$ in the gas phase. These results are consistent with the conclusions reported by Pooja et al. [11].

The stability of the radical formed by the removal of the hydrogen atom can explain the differences in BDE values. The more delocalized spin density in the radical leads to easier formation of radical and thus lower value of BDE [24]. As can be seen from Figure 2, the unpaired electron of the $\mathrm{Cr}$.

Table 2. B3LYP/6-311++G(d,p) BDE, IP, PDE, PA and ETE values of the studied naphthoquinone-urazole hybrids and reference compounds in water. (All values are in kcal energy unit).

\begin{tabular}{|c|c|c|c|c|c|c|}
\hline \multicolumn{2}{|c|}{ Compounds } & \multirow{2}{*}{$\frac{\mathrm{BDE}}{91.26}$} & \multirow[t]{2}{*}{ IP } & \multirow{2}{*}{$\begin{array}{c}\text { PDE } \\
0.88\end{array}$} & \multirow{2}{*}{$\begin{array}{c}\text { PA } \\
14.76\end{array}$} & \multirow{2}{*}{$\frac{\text { ETE }}{106,35}$} \\
\hline \multirow{3}{*}{1} & $\mathrm{O}-\mathrm{H}$ & & & & & \\
\hline & $\mathrm{N}-\mathrm{H}$ & 79.15 & \multirow{2}{*}{120.24} & -11.23 & 27,75 & 81,25 \\
\hline & $\mathrm{C}-\mathrm{H}$ & 75.54 & & -14.85 & 14,76 & 70,11 \\
\hline \multirow{3}{*}{2} & $\mathrm{O}-\mathrm{H}$ & 92.12 & \multirow{3}{*}{121.86} & 0.12 & 16,12 & 105,86 \\
\hline & $\mathrm{N}-\mathrm{H}$ & 79.29 & & -12.71 & 27,95 & 81,19 \\
\hline & $\mathrm{C}-\mathrm{H}$ & 75.60 & & -16.40 & 34,42 & 71,03 \\
\hline \multirow{3}{*}{3} & $\mathrm{O}-\mathrm{H}$ & 88.82 & \multirow{3}{*}{123.27} & -4.60 & 14,85 & 103,82 \\
\hline & $\mathrm{N}-\mathrm{H}$ & 78.63 & & -14.79 & 26,73 & 81,75 \\
\hline & $\mathrm{C}-\mathrm{H}$ & 74.94 & & -18.48 & 27,09 & 77,70 \\
\hline \multirow{3}{*}{4} & $\mathrm{O}-\mathrm{H}$ & 92.34 & \multirow{3}{*}{122.17} & $-0,09$ & 15,61 & 106,58 \\
\hline & $\mathrm{N}-\mathrm{H}$ & 79.50 & & $-12,82$ & 26,91 & 82,44 \\
\hline & $\mathrm{C}-\mathrm{H}$ & 76.20 & & $-16,12$ & 32,02 & 74,03 \\
\hline \multirow{3}{*}{5} & $\mathrm{O}-\mathrm{H}$ & 90.76 & \multirow{3}{*}{119.52} & 1,10 & 15,56 & 105,06 \\
\hline & $\mathrm{N}-\mathrm{H}$ & 78.53 & & $-11,14$ & 28,12 & 80,26 \\
\hline & $\mathrm{C}-\mathrm{H}$ & 74.77 & & -14.90 & 35,68 & 68.94 \\
\hline \multirow{3}{*}{6} & $\mathrm{O}-\mathrm{H}$ & 89.13 & \multirow{3}{*}{118.20} & 0,78 & 14,63 & 104,36 \\
\hline & $\mathrm{N}-\mathrm{H}$ & 78.32 & & -10.03 & 28,06 & 80.11 \\
\hline & $\mathrm{C}-\mathrm{H}$ & 73.26 & & -21.36 & 35.44 & 67.67 \\
\hline \multicolumn{2}{|c|}{ BHT } & 73.33 & 107.44 & -4.27 & 35.80 & 67.38 \\
\hline \multicolumn{2}{|c|}{ 2-HNQ } & 90.80 & 140.10 & -19.44 & 19.70 & 100.95 \\
\hline \multicolumn{2}{|c|}{ 4-PU } & 79.06 & 126.41 & -17.50 & 25.82 & 83.09 \\
\hline
\end{tabular}

radicals in each structure is delocalized over all three rings. Also, low BDE values can attribute to $\pi$-electron delocalization between unpaired electron in $\mathrm{Cr}$ radicals and adjacent $-\mathrm{COCH}=\mathrm{CH}-$ moiety in naphthoquinone ring. This can be understood from spin densities on $\mathrm{C}=\mathrm{O}$ and $\mathrm{C}-\mathrm{OH}$ carbons in the naphthoquinone ring (see Fig 2). When the $\mathrm{C}-\mathrm{H}$ BDE value is considered, it is seen that the lowest $\mathrm{BDE}$ value belongs to $6 \mathrm{C}-\mathrm{H}$ with $73.27 \mathrm{kcal} / \mathrm{mol}$ and the highest BDE value belongs to $3 \mathrm{C}-\mathrm{H}$ with $75.8 \mathrm{kcal}$. The spin densities in the $3 \mathrm{Cr}$ and $6 \mathrm{Cr}$ radicals are 0.416 and 0.141 , respectively. It is seen that the electron attractive $\mathrm{NO}_{2}$ group has decreased $\pi$-electron delocalization of the unpaired electron on $\mathrm{C}$-atom with the adjacent $-\mathrm{COCH}=\mathrm{CH}$ - moiety. 
The calculated IP and PDE parameters for the studied compounds and their radicals are presented in Table 1 and 2. As seen from Table1 and 2, the lowest value of IP is always found for 6 in both environments. It is found that the tendency for IP values is same to that for BDE values. The aqueous medium caused a significant increase in IP values. For example, the IP value of 6 changes from 172.00 to $118.2 \mathrm{kcal} / \mathrm{mol}$ in going from the gas phase to the water medium. The reason of this is that the cation radicals are charged, making them susceptible to the polar solvent environment. That is, it can be said that the electron donation is easier in water.

In comparison with 2-HNQ and 4-PU, IPs of 1-6 are significantly lower than those of 2-HNQ and 4-PU in both environments. This means that the electron donation ability of 1-6 is stronger than that of 2-HNQ and 4-PU. However, IPs of 1-6 are higher than that of BHT in the gas phase and in water. In the gas phase, difference between IP values 6 and BHT is $3 \mathrm{kcal} / \mathrm{mol}$. These trends of PDEs for 1-6 in the both environments are similar with those for BDEs, because the second step of the SET-PT mechanism results in the radical formation, as well. In comparison with the reference compound BHT, the lowest gas phase PDEs $(207.79-215.77 \mathrm{kcal} / \mathrm{mol})$ are lower than those of BHT $(219.38 \mathrm{kcal} / \mathrm{mol})$. This indicates that proton dissociation ability of the studied 1-6 compounds is stronger than BHT.

According to the SPLET mechanism, deprotonation of $\mathrm{O}-\mathrm{H}, \mathrm{N}-\mathrm{H}$ and $\mathrm{C}-\mathrm{H}$ sites and electron transfer tendencies are examined by calculated PA and ETE values in the gas phase and in water. PAs for 1, 2,5 and 6 in the both environments decline in order $\mathrm{C}-\mathrm{H}>\mathrm{N}-\mathrm{H}>\mathrm{O}-\mathrm{H}$, whereas PAs for 3 and 4 decline in order $\mathrm{N}-\mathrm{H}>\mathrm{C}$ $\mathrm{H}>\mathrm{O}-\mathrm{H}$. The reason of this, the anions formed from $3 \mathrm{C}-\mathrm{H}$ and $4 \mathrm{C}-\mathrm{H}$ are more stable by the electron attracting groups $\left(-\mathrm{NO}_{2},-\mathrm{CN}\right)$ attached to the ring. In additional to, according to these sequences, $\mathrm{O}-\mathrm{H}$ sites in all studied compounds have the lowest PA values.
As in PDEs, the PA values in water are significantly lower than those in the gas phase, because of the high solvation enthalpies of proton and anions. This means that the polar medium seem to facilitate the deprotonation process. Moreover, the lowest PAs in the gas phase and in water are lower than those of BHT, 2-HNQ and 4PU. Thus, deprotonation of O-H for 1-6 is easier than BHT, 2-HNQ and 4-PU. In water, all the studied compounds have stronger proton donation ability than the reference compounds.

As can be seen from ETEs in Table 1 and 2, similar to IP $\mathrm{s}$, the lowest ETE in all studied compounds is always found 6 in the gas phase and in water. Also, in general, C-H sites of all studied compounds have the lowest ETEs in both environments. In water, ETEs are higher than the corresponding gas phase values. The differences between ETEs in the gas phase and in water are at 3.46- $16.10 \mathrm{kcal} / \mathrm{mol}$ intervals. Comparing to ETEs and IPs, computed ETEs are significantly lower than IPs in both environments. That is, electron transfer from the anions is more plausible than that from the neutral compound, which in agreement with the results obtained from the literature [25, 26]. Moreover, all ETEs in water are higher than PAs while in the gas phase all ETEs are lower than PAs.

Table 1 and 2 clearly show that the calculated IPs and PAs of the studied compounds are significantly higher than BDEs. Thus, HAT is thermodynamically the most probable process in the gas phase. PAs in water are remarkably lower than BDEs and IPs. Thus, SPLET represents the most probable reaction pathway from thermodynamic point of view in water.

\section{CONCLUSION}

The main results from this study are:

1. The BDEs for $1-6$ decline in order $\mathrm{O}-\mathrm{H}>$ $\mathrm{N}-\mathrm{H}>\mathrm{C}-\mathrm{H}$ in the gas phase. The same sequence was obtained for BDEs in water. The BDE values of $\mathrm{O}-\mathrm{H}$ and $\mathrm{N}-\mathrm{H}$ bonds in all compounds are lower than those of 2HNQ and 4-PU. This result indicates that 
the hybridization increases the antioxidant capacity. In addition, comparing the BDEs of BHT and C-H bonds in 1-6 compounds, it is seen that BDEs in 5 and 6 compounds are especially lower than that of BHT. These results are consistent with the conclusions reported by Pooja et al. [11].

2. The lowest value of IP is always found for 6 in both environments. It is found that the tendency for IP values is same to that for $\mathrm{BDE}$ values. The aqueous medium caused a significant increase in IP values. The reason of this is that the cation radicals are charged, making them susceptible to the polar solvent environment. That is, it can be said that the electron donation is easier in water.

3. PAs for $1,2,5$ and 6 in the both environments decline in order $\mathrm{C}-\mathrm{H}>\mathrm{N}-\mathrm{H}>$ $\mathrm{O}-\mathrm{H}$, whereas PAs for 3 and 4 decline in order $\mathrm{N}-\mathrm{H}>\mathrm{C}-\mathrm{H}>\mathrm{O}-\mathrm{H}$. The reason of this, the anions formed from $3 \mathrm{C}-\mathrm{H}$ and $4 \mathrm{C}-\mathrm{H}$ are more stable by the electron attracting groups $\left(-\mathrm{NO}_{2},-\mathrm{CN}\right)$ attached to the ring. In additional to, according to these sequences, $\mathrm{O}-\mathrm{H}$ sites in all studied compounds have the lowest PA values.

4. Similar to IP $\mathrm{s}$, the lowest ETE in all studied compounds is always found 6 in the gas phase and in water. Also, in general, C$\mathrm{H}$ sites of all studied compounds have the lowest ETEs in both environments. In water, ETEs are higher than the corresponding gas phase values. Comparing to ETEs and IPs, computed ETEs are significantly lower than IPs in both environments. That is, electron transfer from the anions is more plausible than that from the neutral compound, which in agreement with the results obtained from the literature [25, 26].

5. Table 1 and 2 clearly show that the calculated IPs and PAs of the studied compounds are significantly higher than BDEs. Thus, HAT is thermodynamically the most probable process in the gas phase. PAs in water are remarkably lower than BDEs and IPs. Thus, SPLET represents the most probable reaction pathway from thermodynamic point of view in water.

\section{Acknowledgement}

This research was made possible by TUBITAK ULAKBIM, High Performance and Grid Computing Center (TR-Grid e-Infrastructure).

\section{REFERANCES}

[1]. Mokini Z., Marcovecchio, M. L., \& Chiarelli, F., Molecular pathology of oxidative stress in diabetic angiopathy: role of mitochondrial and cellular pathways, Diabetes Research and Clinical Practice, 87-3 (2010) 313-321.

[2]. Kamkar, A., Javan, A. J., Asadi, F., \& Kamalinejad, M., The antioxidative effect of Iranian Mentha pulegium extracts and essential oil in sunflower oil, Food and Chemical Toxicology, 48-7 (2010) 17961800.

[3]. Kovacic, P., \& Somanathan, R., Recent developments in the mechanism of anticancer agents based on electron transfer, reactive oxygen species and oxidative stress. Anti-Cancer Agents in Medicinal Chemistry (Formerly Current Medicinal Chemistry-Anti-Cancer Agents), 11-7 (2011) 658-668.

[4]. Salustiano, E. J., Netto, C. D., Fernandes, R. F., da Silva, A. J., Bacelar, T. S., Castro, C. P., .. \& Costa, P. R., Comparison of the cytotoxic effect of lapachol, $\alpha$-lapachone and pentacyclic 1, 4-naphthoquinones on human leukemic cells, Investigational new drugs, 28-2 (2011) 139-144.

[5]. Gaikwad, P., Barik, A., Priyadarsini, K. I., \& Rao, B. S. M., Antioxidant activities of phenols in different solvents using DPPH assay, Research on chemical intermediates, 36-9 (2011) 1065-1072.

[6]. Kuwahara, R., Hatate, H., Yuki, T., Murata, H., Tanaka, R., \& Hama, Y., Antioxidant property of polyhydroxylated naphthoquinone pigments from shells of purple sea urchin Anthocidaris 
crassispina, LWT-Food Science and Technology, $42-7$ (2009) 1296-1300.

[7]. Jacobson, C. R., A. D. Adamo, and C. E. Cosgrove. "US Patent, 3,663,564, 1972." Chem. Abstr. Vol. 76. 1972.

[8]. Wellington, K. W., Understanding cancer and the anticancer activities of naphthoquinones-a review. RSC Advances, 5-26 (2015) 20309-20338.

[9]. T. Jikihara, K. Matsuya, H. Ohta, S. Suzuki and O. Wakabayashi, US Pat. 4249934 A, 1981, Chem. Abstr., 95 (1981) 62219 y.

[10]. R. A. Izydore and I. H. Hall, US Pat. 4866058, 1990, Chem. Abstr.,112 (1990) $151876 \mathrm{x}$.

[11]. B. V. Bredow and H. Brechbuehler, Ger. Offen. 2343347 A1, Chem. Abstr., 80 (1974) $140210 \mathrm{~s}$.

[12]. Saluja, P., Khurana, J. M., Nikhil, K., \& Roy, P., Task-specific ionic liquid catalyzed synthesis of novel naphthoquinone-urazole hybrids and evaluation of their antioxidant and in vitro anticancer activity. RSC Advances, 4.65 (2014) 34594-34603.

[13]. Wright, J. S., Johnson, E. R., \& DiLabio, G. A., Predicting the activity of phenolic antioxidants: theoretical method, analysis of substituent effects, and application to major families of antioxidants. Journal of the American Chemical Society, 123-6 (2001) 1173-1183.

[14]. Bartmess, J. E., Thermodynamics of the electron and the proton. The Journal of Physical Chemistry, 98-25 (1994) 64206424.

[15]. Klein, E., Rimarcik, J., \& Lukes, V., DFT/B3LYP study of the O-H bond dissociation enthalpies and proton affinities of para-and meta-substituted phenols in water and benzene, Acta Chim. Slovaca, 22 (2009) 37-51.

[16]. Rimarčík, J., Lukeš, V., Klein, E., \& Ilčin, M., Study of the solvent effect on the enthalpies of homolytic and heterolytic N$\mathrm{H}$ bond cleavage in $\mathrm{p}$-phenylenediamine and tetracyano-p-phenylenediamine, Journal of Molecular Structure: THEOCHEM, 952(1-3) (2010) 25-30.
[17]. Parker, V. D., Homolytic bond (HA) dissociation free energies in solution. Applications of the standard potential of the $(\mathrm{H}+/ \mathrm{H}$. bul.) couple, Journal of the American Chemical Society, 114-19 (1992) 7458-7462.

[18]. Bizarro, M. M., Cabral, B. J. C., de Santos, R. M. B., \& Simões, J. A. M., Substituent effects on the $\mathrm{OH}$ bond dissociation enthalpies in phenolic compounds: agreements and controversies, Pure and Applied Chemistry, 71-8 (1999) 1609-1610.

[19]. M.A. Robb, J.R. Cheeseman, M.J. Frisch, G.W. Trucks,H.B. Schlegel, G.E. Scuseria, M.A. Robb, J.R. Cheeseman, G. Scalmani, V. Barone, B. Mennucci, G.A. Petersson, H. Nakatsuji,M. Caricato, X. Li,H.p.Hratchian, A.F. Izmaylov, J. Bloino, G. Zheng, J.L. Sonnenberg, M. Hada, M. Ehara, K. Toyota, R. Fukuda, J.Hasegawa, M. Ishida, T. Nakajima, Y. Honda, O. Kitao, H. Nakai, T. Vreven, J.A.Montgomery, Jr., J.E. Peralta, F. Ogliaro,M. Bearpark, J.J. Heyd, E. Brothers, K.N. Kudin, V.N. Staroverov, R. Kobayashi, J. Normand, K. Raghavachari, A. Rendell,J.C. Burant, S.S. Iyengar, J.Tomasi, M. Cossi, N. Rega, J.M. Millam, M.Klene, J.E. Knox, J.B. Cross,V. Bakken, C. Adamo, J.Jaramillo, R. Gompert, R.E. Stratmann, O. Yazyev, A.J. Austin, R. Cammi, C. Pomelli, J.W.Ochterski, R.L. Martin,K. Morokuma, V.G. Zakrzewski, G.A. Voth, P. Salvador, J.J. Dannenberg, S. Dapprich, A.D. Daniels, O. Farkas, J.B. Foresman, J.V.Ortiz, J. Cioslowski, andD.J. Fox, Gaussian 09, Revision C.01 (Gaussian Inc., Wallingford,CT, (2010).

[20]. Becke, A. D., Density-functional thermochemistry. III. The role of exact exchange, The Journal of chemical physics, 98-7 (1993) 5648-5652.

[21]. Cances, E., Mennucci, B., \& Tomasi, J., A new integral equation formalism for the polarizable continuum model: Theoretical background and applications to isotropic and anisotropic dielectrics. The Journal of chemical physics, 107-8 (1997) 3032-3041. 
[22]. Özbakır Işın, D., Theoretical study on the investigation of antioxidant properties of some hydroxyanthraquinones, Molecular Physics, 114-24 (2016) 3578-3588.

[23]. Kabanda, M. M., Tran, V. T., Seema, K. M., Serobatse, K. R., Tsiepe, T. J., Tran, Q. T., \& Ebenso, E. E., Conformational, electronic and antioxidant properties of lucidone, linderone and methyllinderone: DFT, QTAIM and NBO studies, Molecular Physics, 113-7 (1015) 683-697.

[24]. Cai, W., Chen, Y., Xie, L., Zhang, H., \& Hou, C., Characterization and density functional theory study of the antioxidant activity of quercetin and its sugarcontaining analogues, European Food Research and Technology, 238-1 (2014) 121-128.

[25]. Markovic, Zoran S., Slavko V. Mentus, and Jasmina M. Dimitrić Marković., Electrochemical and density functional theory study on the reactivity of fisetin and its radicals: implications on in vitro antioxidant activity, The journal of physical chemistry A 113-51 (2009) 14170-14179.

[26]. Leopoldini, M., Russo, N., \& Toscano, M., Gas and liquid phase acidity of natural antioxidants, Journal of agricultural and food chemistry, 54-8 (2006) 3078-3085.

[27]. Marković, Z., Jeremić, S., Marković, J. D., Pirković, M. S., \& Amić, D., Influence of structural characteristics of substituents on the antioxidant activity of some anthraquinone derivatives, Computational and Theoretical Chemistry, 1077 (2016) 2531. 